\title{
Biomaterials: Polylactic Acid and 3D Printing Processes for Orthosis and Prosthesis
}

\author{
ROXANA MICLAUS ${ }^{1 *}$, ANGELA REPANOVICl ${ }^{2}$, NADINNE ROMAN ${ }^{1}$ \\ ${ }^{1}$ Transilvania University of Brasov, Faculty of Medicine, 56 Nicolae Balcescu Str., 500019, Brasov, Romania \\ ${ }^{2}$ Transilvania University of Brasov, Faculty of Product Design and Environment, 1 Universitatii Str., 500068, Brasov, Romania
}

\begin{abstract}
Since the development of 3D printing, over the past decades, the domain of application has evolved significantly! Concerning the orthosis and prosthesis manufacturing, the 3D printing offers many possibilities for developing new medical devices for people with disabilities. Our paper wish to synthetize the main 3D printing methods and the biomaterial properties which can be used in orthosis and prosthesis manufacturing, like polylactic acid or acrylonitrile butadiene styrene. Fused Deposition Modeling and Stereo lithography are most used for medical devices manufacturing and usually using polylactic acid, considering the properties of this polymer and de organic componence.
\end{abstract}

Keywords: biomaterials, 3D printing, medical rehabilitation, polylactic acid

Since the development of 3D printing, over the past decades, the domain of application has evolved significantly! In medicine, and especially concerning prosthesis and orthosis devices manufacturing, the design and the cost of these outfits represent important elements in the development of the industry, leading in turn the increase of quality of life of patients with disabilities and low social status. Besides 3D printing aspect of these devices really matter and the quality of material they are made of, especially their use involving prolonged contact with the human body. We approach the use of polylactic acid(PLA) which is biodegradable and has similar characteristics to polypropylene (PP), polyethylene (PE) or polystyrene (PS). The mechanical properties of PLA may vary from stiff, high- strength materials to soft, elastic materials, determined by different parameters such as polymer structure, molecular weight, material formulation (blends, plasticizers, composites) and orientation. It also known originally as a brittle material, with lower impact strength and elongation break, similar to polymerpolystyrene [1]. PLA is a versatile polymer made from renewable agricultural raw materials, which are fermented to lactic acid [2].

\section{D Printing of Biomaterials}

Three-dimensional printing(3D) is layered manufacturing, rapid prototyping or solid free form fabrication, represents the direct fabrication of parts, layerby-layer, guided by digital information from a computeraided design file, without any part-specific tooling [3]. But this is only one type of 3D printing process, that is well known, in the next table, we will summarize the main 3D printing process used worldwide.

There are existing many forms of 3D printing, but the printing process, the finish of the prototypes, the materials used and the cost of the manufacturing depends on many variables, from the printed pieces size, the properties of the materials used and providing equipment manufacturer. Through this article we wish to synthesize the main methods of 3D printing and biomaterials properties that are used in making medical devices, butespecially in terms of manufacturing orthoses and prostheses used by people with disabilities and used in physiotherapy or medical rehabilitation.

Table 1

THE MAIN 3D PRINTING PROCESSES

\begin{tabular}{|c|c|c|c|c|}
\hline Technology & Process & Material type & Advantages and disadvantages & Ref. \\
\hline $\begin{array}{l}\text { FDM - Fused } \\
\text { Deposition } \\
\text { Modeling }\end{array}$ & $\begin{array}{l}\text { The device has a } \\
\text { movabile head which } \\
\text { deposit a thread of } \\
\text { molten materials onto a } \\
\text { substrate. The builted } \\
\text { material is heated with } \\
0,5 \text { degrees after its } \\
\text { melting point, so that it } \\
\text { solidifies after } 0,1 \text { after } \\
\text { extrusion and cold } \\
\text { welds to the previous } \\
\text { layers. }\end{array}$ & $\begin{array}{l}\text { Structural and } \\
\text { biopolymers, } \\
\text { ceramic-polymer, or } \\
\text { metalpolymer } \\
\text { composites: ABS } \\
\text { (acrylonitrile butadiene } \\
\text { styrene), PLA (polylactic } \\
\text { acid), PVA (soluble), PC } \\
\text { (polycarbonate), } \\
\text { polyethylene HDPE, } \\
\text { polypropylene, elastomer, } \\
\text { polyamide, tricalcium } \\
\text { phosphate }\end{array}$ & $\begin{array}{l}\text { Advantage } \\
\text { - Easy to use, large variety of cheap, } \\
\text { non-toxic materials, affordable price for } \\
\text { printing machines and materials } \\
\text { Disadvantage } \\
\text { - Material restriction related to } \\
\text { thermoplastic polymers } \\
\text { - Low construction speed } \\
\text {-Areas may appear uneven }\end{array}$ & $\begin{array}{c}{[3]} \\
{[4]}\end{array}$ \\
\hline
\end{tabular}




\begin{tabular}{|c|c|c|c|c|}
\hline \multirow[t]{2}{*}{$\begin{array}{l}\text { SLA - } \\
\text { Stereolithography } \\
-\end{array}$} & \multirow{2}{*}{$\begin{array}{l}\text { The use of a laser beam } \\
\text { with UV light for } \\
\text { solidifying a liquid } \\
\text { photopolymer resins } \\
\text { located inside the } \\
\text { construction printer's } \\
\text { tank. }\end{array}$} & \multirow{2}{*}{$\begin{array}{l}\text { Photo-curable polymers, } \\
\text { or a composite mixture of } \\
\text { epoxide resins and } \\
\text { cationic photoinitiators, } \\
\text { including PLA }\end{array}$} & $\begin{array}{l}\text { Advantages: oversize pieces } \\
\text { manufacturing, high temperature } \\
\text { resistance }\end{array}$ & \multirow[t]{2}{*}{$\begin{array}{l}{[5]} \\
{[6]} \\
{[7]}\end{array}$} \\
\hline & & & $\begin{array}{l}\text { Disadvantages: -Polymers used in 3D } \\
\text { printing must have a low volume } \\
\text { shrinkage at polymerization, for } \\
\text { avoiding the solid object distortion. } \\
\text {-The surface not well finished } \\
\text {-High price of device } \\
\text { - It must be studied and developed } \\
\text { further biocompatibility in medical use }\end{array}$ & \\
\hline \multirow[t]{2}{*}{$\begin{array}{l}\text { DLP - Digital } \\
\text { Light Processing - }\end{array}$} & \multirow[t]{2}{*}{$\begin{array}{l}\text { Liquid resins solidified } \\
\text { by UV light, based on a } \\
\text { Digital Micromirror } \\
\text { Device(DMD)-mirror } \\
\text { modulation matrices for } \\
\text { shaping light in space }\end{array}$} & \multirow[t]{2}{*}{$\begin{array}{l}\text { Resins, photopolymers, } \\
\text { transparent resins, } \\
\text { polymer-based wax }\end{array}$} & $\begin{array}{l}\text { Advantages: Accuracy and finishing } \\
\text { printed parts is high } \\
\text { - wide range of biomedical materials } \\
\text { including resins (certified for use in the } \\
\text { medical field)-including PLA }\end{array}$ & \multirow[t]{2}{*}{$\begin{array}{l}{[8]} \\
{[9]}\end{array}$} \\
\hline & & & Disadvantages: High cost devices & \\
\hline \multirow[t]{2}{*}{$\begin{array}{l}\text { SLS - Selective } \\
\text { Laser Sintering }\end{array}$} & \multirow[t]{2}{*}{$\begin{array}{l}\text { It uses a high power } \\
\text { laser beam for sintering } \\
\text { powder in layers } \\
\text { thereby achieving the } \\
\text { desired 3D model. }\end{array}$} & \multirow[t]{2}{*}{$\begin{array}{l}\text { powders (thermo) plastic } \\
\text { (nylon, polyamide, } \\
\text { polystyrene, elastomers, } \\
\text { composites), powdered } \\
\text { metal (steel, titanium } \\
\text { alloys), ceramic powders, } \\
\text { glass powders }\end{array}$} & $\begin{array}{l}\text { Advantages: Accuracy and finishing } \\
\text { printed parts is very high } \\
\text { - wide range of materials } \\
\text { - construction's geometries very } \\
\text { complex without material support, } \\
\text { - It requires no post processing } \\
\text { operations }\end{array}$ & \multirow[t]{2}{*}{$\begin{array}{l}{[10]} \\
{[11]}\end{array}$} \\
\hline & & & $\begin{array}{l}\text { Disadvantages: } \\
\text {-High cost devices -expensive material } \\
\text { printing } \\
\text {-average finish area (compared to SLA) }\end{array}$ & \\
\hline $\begin{array}{l}\text { SLM - Selective } \\
\text { Laser Melting / } \\
\text { Direct Metal Laser } \\
\text { Sintering - }\end{array}$ & $\begin{array}{l}\text { SLS technology sub- } \\
\text { branch } \\
\text { SLM metal powders } \\
\text { used as building } \\
\text { material are melted and } \\
\text { welded together using a } \\
\text { high-power laser. }\end{array}$ & metal powders & $\begin{array}{l}\text { Selective Laser Melting rather be } \\
\text { framed in the field of rapid prototyping } \\
\text { devices than in that of } 3 \mathrm{D} \text { printing. }\end{array}$ & [12] \\
\hline \multirow[t]{2}{*}{$\begin{array}{l}\text { 3DP - Three } \\
\text { dimensional inkjet } \\
\text { printing }\end{array}$} & \multirow[t]{2}{*}{$\begin{array}{l}\text { It uses inkjet printing } \\
\text { technology for powder } \\
\text { solidification. The } \\
\text { powder is inserted in } \\
\text { the printer construction } \\
\text { room and the particles } \\
\text { are bonded with a } \\
\text { binder material. }\end{array}$} & \multirow[t]{2}{*}{$\begin{array}{l}\text { powder composed of a } \\
\text { synthetic polymer } \\
\text { polylactide-coglycolide or } \\
\text { poly-PLA with organic } \\
\text { solvent as binder natural, } \\
\text { polymer powder, } \\
\text { polyethylene glycol } \\
\text { (PEG), }\end{array}$} & $\begin{array}{l}\text { Advantage } \\
\text { - Easy to incorporate and direct control } \\
\text { both drug } \\
\text { and biomolecules (proteins and } \\
\text { living cells) } \\
\text {-No limitations on macroarchitecture } \\
\text {-Great range of materials }\end{array}$ & \multirow[t]{2}{*}{$\begin{array}{l}{[3]} \\
{[13]}\end{array}$} \\
\hline & & & $\begin{array}{l}\text { Disadvantages: } \\
\text { - Post-processing may be needed } \\
\text { for some materials. } \\
\text { - Layer thickness must be greater then } \\
\text { porogen particle size } \\
\text {-Use of organic solvents as binders } \\
\text { Costs: depending on production, for } \\
\text { industrial manufacuring is high price }\end{array}$ & \\
\hline \multirow[t]{2}{*}{$\begin{array}{l}\text { LOM - Laminated } \\
\text { Object } \\
\text { Manufacturing }\end{array}$} & \multirow[t]{2}{*}{$\begin{array}{l}\text { The 3D object is } \\
\text { manufactured using } \\
\text { laminated paper or } \\
\text { plastic materials, } \\
\text { bonded and cut with a } \\
\text { laser or knife. }\end{array}$} & \multirow[t]{2}{*}{$\begin{array}{l}\text { Plastics, composites, } \\
\text { ceramics, metals and } \\
\text { various organic and } \\
\text { inorganic materials with } \\
\text { different chemical and } \\
\text { mechanical properties }\end{array}$} & $\begin{array}{l}\text { Advantages: low cost materials } \\
\text {-used primarily for creating scaled } \\
\text { models and conceptual prototypes that } \\
\text { can be tested for form or design. }\end{array}$ & \multirow[t]{2}{*}{ [14] } \\
\hline & & & $\begin{array}{l}\text { Disadvantages: usually used only on } \\
\text { prototypes, because is doesn't create } \\
\text { accurate models }\end{array}$ & \\
\hline
\end{tabular}




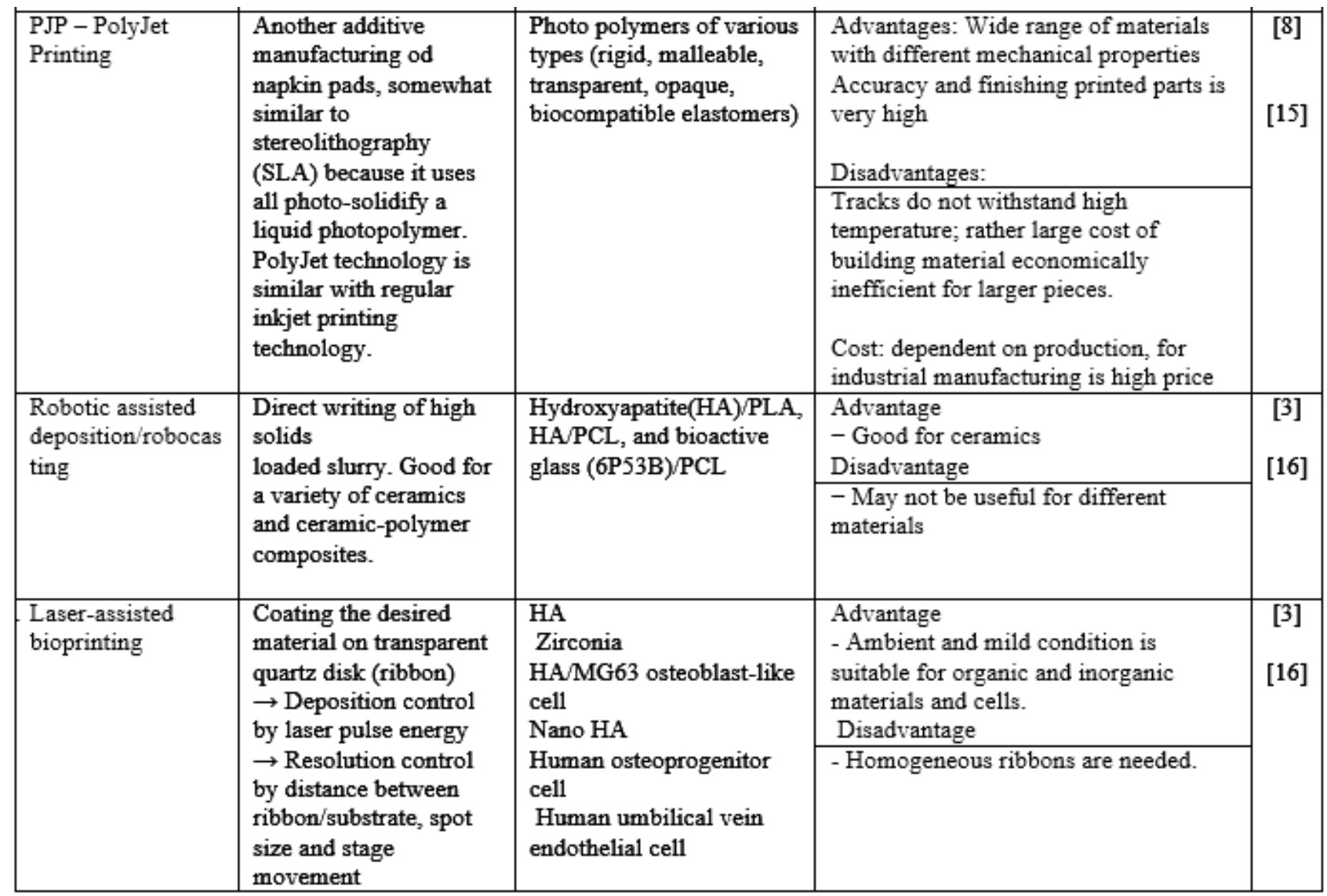

\section{Biomaterials used in orthosis and prosthesis 3D} printing

Biomaterials as organic polymer composite have some advantages for medical applications advocated by researchers: 1) are mostly more compliant with biological tissue than metal and ceramics; 2) have strengths of the same order of magnitude with hard tissue; 3) the composition of polymers and other materials used for obtaining the composite material is closer to the mechanical and biological properties to those of biological hard tissue; 4)design variability [17]. The polymers are easy to process into the desired structures, having a low risk concerning toxicity, the autoimmune response and the infection, being suitable for biomedical sciences [18]. The length of polymer chains and the molecular weight are responsible with degradation process, the higher molecular weight leads to slower degradation due to lengthy polymer chains[19].

\section{Polylactic acid (PLA)}

In biomedical applications concerning orthosis and prosthesis, this polylactic acid polymer is the most commonly used, so it has been massively modified by incorporating different organic and inorganic components. Polylactic acid is a versatile polymer made from renewable agricultural raw materials, which are fermented to lactic acid. The lactic acid is then via a cyclic dilactone, lactide, ring opening polymerized to the wanted polylactic acid [20]. PLA has a slow degradation rate and it provides opportunity for the production of long-term orthopedic implants. Different configuration polymers from PLA are given by the crystallinity ( $\alpha, \beta$, and $\gamma$ forms), with different melting points, from 185,175 and $235^{\circ} \mathrm{C}$. Because the PLA has a hydrophobic nature, its degradation in the body decrease the PH of surrounding tissue, therefore, it is being changed into polymers with a more hydrophilic nature, which degrades into less acid products:
PLA combined with Bioactive Glasses (BG-40\%), Carbonated apatite $(30 \%), \mathrm{HA}(50 \%)$, Calcium phosphate(50\%) and Hallosyte nanotube(10\%) offers bioactivity and neutralize the acidic degradation

PLA combined with Polyurethane (PU-50\%), Poly ( $\varepsilon$ caprolactone) (PCL) (50\%), PEG (20\%), offers mechanical performance [18].

Lactic acid has a chiral character and are several different forms of polylactide: poly-L-lactide (PLLA) is the product resulting from polymerization of $\mathrm{L}$, $\mathrm{L}$-lactide (also known as L-lactide). PLLA has, a melting temperature $173-178^{\circ} \mathrm{C}$ [21]. Polymer molecular weight and stereochemistry, in the case of the chiral lactide monomer, have been shown to dramatically affect the physical properties of the polymer and crystallinity and thermal properties may also be controlled by polymer blending [22].

The melting temperature of PLLA may be raised by $40-50^{\circ} \mathrm{C}$ and its heat deflection temperature can be raised from approximately $60^{\circ} \mathrm{C}$ to up to $190^{\circ} \mathrm{C}$ by physically blending the polymer with PDLA (poly-Dlactide) [23].

\section{Orthosis manufacturing}

Various rapid prototyping(RP) and new additive manufacturing(AM) has developed during the last decade and gained the attention of scientists and manufacturers. In medical area, the orthosis are used for many purposes, depending on the patient impairment, it might be used as braces for peripherical nerves dysfunctions with muscle altered function, to use a low power setting, to allow patient to use his own muscle power muscle with rehabilitation device [24] ,for improve gait performance for persons with impaired lower limb function [25] or with the purpose to optimize the support of a limb [26], used in rheumatology, traumatology or other articulations inflammatory processes. 


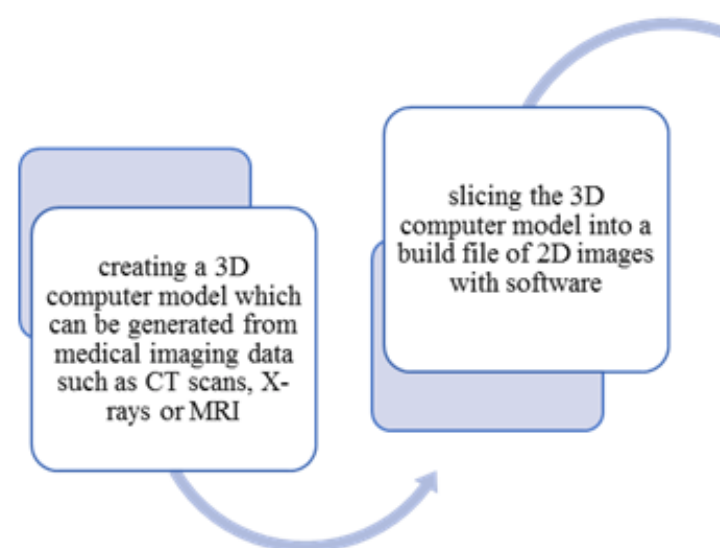

The manutacturing process tollows the next steps: 1 ) it is scanned the body part for which the custom orthosis need to be realized, with dynamically scanning and different positions, using usually computer tomography, magnetic resonance imaging and laser scanning $[26,27] ; 2$ ) the analyze of the plurality of scans to identify the body part with the unnatural position or motion impairment (the custom orthosis suppose preventing the excessive movement of at least one location of the body part and to enable the natural movement for the healthy body parts) [26]; 3) creating an digital negative model and 4) using a computer aided design software is created the orthosis shape; 5) with different types of 3D printing devices and processes, the personalized orthosis is created in short time[28].

Mario C. et al test three types of materials using SLS 3D printing and the results shown that the best mechanical damping characteristics is registered by Rilsan ${ }^{\mathrm{TM}} \mathrm{D} 80$ (best)(polyamides), followed by DuraForm ${ }^{\mathrm{TM}}$ PA and DuraForm ${ }^{\mathrm{TM}} \mathrm{GF}$ (worst) [25]. But the thermoset materials used in orthosis manufacturing, which uses resin, matrix and promoter, are lightweight and stronger. The thermosets suppose combing the thermoplastic materials (also biomaterials like PLA) and make fiber -reinforced materials, using nylon, carbon and glass fiber [29]. In creating a hand orthosis, Gabriele B., argue for a good design and production of orthosis using the 3D printing process, by offering a high degree of comfort and tolerability and gives the opportunity to the clinicians to indicate pressure zones and to create fully personalized orthosis, enabling the therapeutic indications in medical rehabilitation [30].

Scott T., 2013 studied the medical effectiveness on 3D orthosis printing, using PLA, for a ankle-foot orthosis used to correct the prone foot. The results emerged from the research reveals that foot type orthosis has a significant role in the muscle activity of biceps femurs, vastus lateralis and vastus lateralis. Personalized orthosis has been shown to affect pressure distribution in a number of patients, although even if the changes in pressure were small and it is not known if it has clinical relevance. The orthosis manufacturing using 3D printing process and the material types need further investigations [31].

Some of the obstacles claimed by the researchers refers to the CAD software which is notyet sufficiently developed for using the process in a clinical setting, being necessary to accomplish many steps and measurement in 3D orthosis printing [28].

\section{Conclusions}

According to Hospital for Special Surgery from the United States, Medical Rehabilitation or Physiatry, is a specialized medical area addressed to the patients who have been disabled as a result of a disease, condition, disorder or injury. The physiatrists are focusing on personalized method of treatment to improve their patient's quality of life, treat a wide scope of cases, from brain and spinal cord injuries to stroke and burn victims. The physiatrists direct a multidisciplinary team of professionals, like physical therapists, occupational therapists, recreational therapists, rehabilitation nurses, psychologists, social workers and collaborate with the specialized clinicians like neurologist, podiatrist, rheumatologist and other specialized doctors [32]. Training in health promotion is not well developed around the world and many professionals have poor knowledge especially in the newest well-being standards [33]. So, the rehabilitation addressability is on a large scale and the medical professionals from this area need to develop and build solid and functional team works, with the purpose to improve the patient's quality of life or conditions, as it was stated, the treatment must be personalized. With the use of 3D printing devices and processes, in the orthosis manufacturing procedures, the physical medicine or rehabilitation area has the opportunity to improve the medical services and actions and also develop new prototypes or functional devices to improve the patient's conditions. But we see mandatory the collaborating of physical medicine rehabilitation specialists, design engineers, materials or biomaterials engineers and also computing software technology specialists for creating functional and easily manufacturing medical devices (orthosis) for an improved process of rehabilitation and science development.

\section{References}

1.LEE, T. S., RAHMAT, A. R. , RAHMAN, W. A. W. A. , 5 - Mechanical Properties of Poly (lactic Acid). Polylactic Acid: Elsevier; 2013, p.177178

2.MATHEW, A.P., OKSMAN, K., SAIN, M., The Effect of Morphology and Chemical Characteristics of Cellulose Reinforcements on the Crystallinity of Polylactic Acid. Journal of Applied Polymer Science. Vol. 101, $300-310$ (2006), p.300-311.

3.BANDYOPADHYAY, A., BOSE, S., DAS, S., 3D printing of biomaterials. MRS Bulletin. 2015, p.108-115.

4.PHAM, D.T., GAULT, R.S., A comparison of rapid prototyping technologies. International J ournal of Machine Tools \& Manufacture. Oct-Nov 1998; Volume: 38(Issue: 10-11), p. 1257-1287.

5.CRIVELLO, J.V., REICHMANIS, E., Photopolymer Materials and Processes for Advanced Technologies. Chem. Mater. 2014, p.533-548. 6.BAROLI, B., Photopolymerization of biomaterial. Journal of Chemical Technology and Biotechnology. 2006; Vol 81, p.491-499.

7.OSTHUIZEN, G.A., HAGEDORN-HANSEN, D., GERHOLD, T., Aluation of rapid product development technologies for production of prosthesis in developing communities. Paper presented at: SAIIE25 Proceedings, 2013.

8.GROTH, C., KRAVITZ, N. D., JONES, P. E., GRAHAM, J. W., REDMOND W. R., Three-Dimensional Printing Technology. J ournal of Clinical Orthodontics. 2014; 48, p.475-485. 
9.DEAN, D., MOTT, E., LUO, X., BUSSO, M., WANG, M., VORWALD, C., SIBLANI, A., FISHER J.P., Determination of resin components for continuous Digital Light Processing (CDLP) additive manufacture of resorbable tissue engineering scaffolds. Paper presented at: 6th International Conference on Advanced Research in Virtual and Physical Prototyping (VRatP), 2014.

10.FAUSTINI, M.C., NEPTUNE, R.R., CRAWFORD, R.H., STANHOPE, S.J., Manufacture of passive dynamic ankle-foot orthoses using selective laser sintering. IEEE Transactions on Biomedical Engineering. 2008;55(2), p.784-790.

11.KRUTH, J.P., LEVY, G., SCHNIDEL, R., CRAEGHS, T., YASA, E., Consolidation of Polymer Powders by Selective Laser Sintering. Paper presented at: Proceedings of the 3rd International Conference on Polymers and Moulds Innovations, 2008.

12.KRUTH, J.P., MERCELIS, P., VAN VAERENBERGH, J., FROYEN, L., ROMBOUTS, M., Binding mechanisms in selective laser sintering and selective laser melting. Rapid Prototyping Journal. 2005;11(1), p.26-36.

13.CHIA, H.N., WU, B.M., Recent advances in 3D printing of biomaterials. Journal of Biological Engineering. 2015, p.1-14.

14.NEGI, S., DHIMAN, S., SHARMA, R.K., Basics and applications of rapid prototyping medical models. Rapid Prototyping Journal. 2014;20(3), p.256-267.

15.STANEK, M., MANAS, D., MANAS, M., NAVRATIL, J., KYAS, K., SENKERIK, V., SKROBAK, A. Comparison of Different Rapid Prototyping Methods. International J ournal of Mathematics and Computers in Simulation. 2012;6(6), p.550-557.

16.BOSE, S., VAHABZADEH, S., BANDYOPADHYAY, A., Bone tissue engineering using 3D printing. Materials Today. 2013;16(12), p.496504.

17.YAN, C., SHI, Y., YANG, J., LIU, J., Multiphase Polymeric Materials for Rapid Prototyping and Tooling Technologies and Their Applications. Composite Interfaces. 2012, p.257-271.

18.MANAVITEHRANI, I., FATHI, A., BADR, H., DALY, S., SHIRAZI A.N., DEHGHANI F., Biomedical Applications of Biodegradable Polyesters. Polymers. 2016.

19.LIGGINS, R.T., BURT, H.M., Paclitaxel loaded poly (I-lactic acid) microspheres: Properties of microspheres made with low molecular weight polymers. Int. J. Pharm. 2001, p.19-33.

20.OKSMAN, K., SKRIFVARS, M., SELIN, J-F., Natural fibers as reinforcement in polylactic acid (PLA) composites. Composite Science Technology. 2003, p.1317-1324.
21.SODERGARD, A., STOLT, M., Properties of lactic acid based polymers and their correlation with composition. Progress in Polymer Science. 2002: p.123-1163.

22.KAIHARA, S., MATSUMURA, S., MIKOS, A.G., FISHER, J.P., Synthesis of poly(L-lactide) and polyglycolide by ring-opening polymerization. Nature Protocols 2. 2007, p.2767 - 2771.

23.LAM, C. X. F., OLKOWSKI, R., SWIESZKOWSKI, W.., TAN, K. C., GIBSON, I., HUTMACHER, D. W., Mechanical and in vitro evaluations of composite PLDLLA/TCP scaffolds for bone engineering. Virtual and Physical Prototyping. 2008, p.193-197.

24.ROY K.D., Inventor. US8048007 B2, 2005.

25.FAUSTINI, M.C., NEPTUNE, R.R., CRAWFORD, R.H., STANHOPE, S.J., Manufacture of Passive Dynamic Ankle-Foot. IEEE Transactions on Biomedical Engineering, 2008, p.784-790.

26.ZACHARIASEN, J .T., Inventor. US20140180185 A1, 2014.

27.HIEU, L.C., ZLATOV, N., VANDER, S.J ., BOHEZ, E., BINH, P.H., KHANH, L., ORIS, P., TOSHEV, Y., Medical rapid prototyping applications and methods. Emerald Insight. 2005, p.284-292.

28.TELFER, S., PALLARI, J., MUNGUIA, J., DALGARNO, K., MCGEOUGH, M., WOODBURN, J., Embracing additive manufacture: implications for foot and ankle orthosis design. BMC Musculoskeletal Disorders. 2012.

29.COPPAARD, B., LOHMAN, H., Introduction to Orthotics: A Clinical Reasoning and Problem-Solving Approach. Riverport Lane, Elsevier; $4^{\mathrm{TH}}$ Edition, 2015.

30.BARONIO, G., HARRAN, S., SIGNORONI, A., A Critical Analysis of a Hand Orthosis Reverse Engineering and 3D Printing Process. Applied Bionics and Biomechanics. 2016

31.TELFER, S., ABBOT, M., STEULTJENS, M., RAFFERTY, D., WOODBURN, J., Dose-response effects of customized foot orthoses on lower limb muscle activity and plantar pressures in pronated foot type. Gait \& Posture. 2013, p.443-449.

32.HOSPITAL FOR SPECIAL SURGERY, What is Physiatry. Hospital for Special Surgery. 2016. Available at: https://www.hss.edu/what-isphysiatry.asp.

33.ROGOZEA, L., MICLAUS, R., REPANOVICI, A., BURTEA, V., Health promotion - strategies and topics Educating the students from nursing and optometry department. Paper presented at: 9th WSEAS International Conference on Education and Educational Technology (EDU '10), 2010

$\overline{\text { Manuscript received: } 15.06 .2016}$ 